In Cooperation With the Northeast Ohio Regional Sewer District

\title{
Results From a Microbial Source-Tracking Study at Villa Angela Beach, Cleveland, Ohio, 2007
}

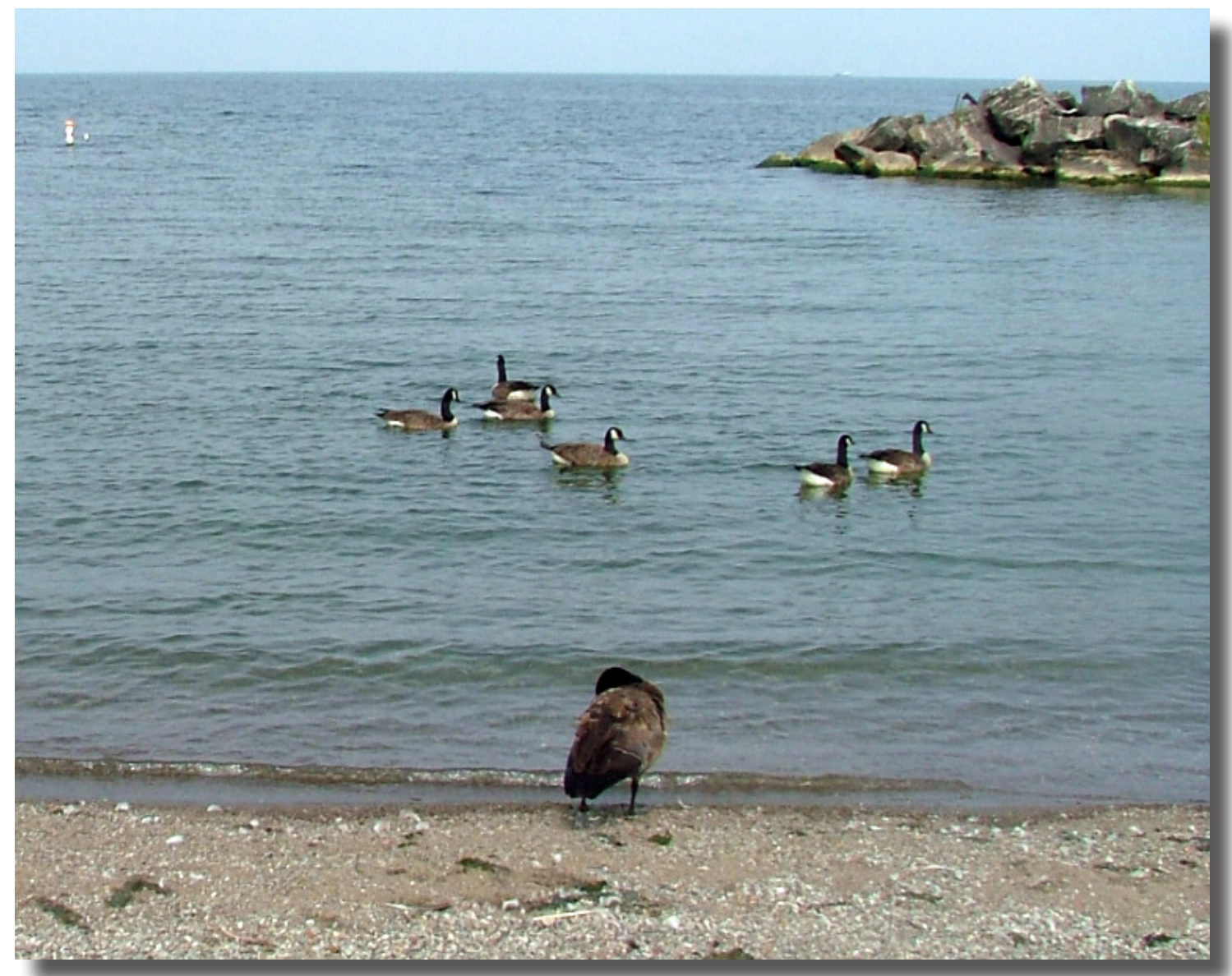

Open-File Report 2009-1160 
Cover image: Congregations of Canada geese onshore and offshore are a common sight at Villa Angela Beach, in Cleveland Ohio. Their presence is of concern because their contribution of Escherichia coli to the aquatic environment confounds efforts to assess the quality of lake water for recreation. 
In Cooperation With the Northeast Ohio Regional Sewer District

\section{Results From a Microbial Source-Tracking Study at Villa Angela Beach, Cleveland, Ohio, 2007}

By Rebecca N. Bushon, Erin A. Stelzer, and Donald M. Stoeckel

Open-File Report 2009-1160

U.S. Department of the Interior

U.S. Geological Survey 


\title{
U.S. Department of the Interior KEN SALAZAR, Secretary
}

\section{U.S. Geological Survey \\ Suzette M. Kimball, Acting Director}

\author{
U.S. Geological Survey, Reston, Virginia 2009
}

For product and ordering information:

World Wide Web: http://www.usgs.gov/pubprod

Telephone: 1-888-ASK-USGS

For more information on the USGS - the Federal source for science about the Earth, its natural and living resources, natural hazards, and the environment:

World Wide Web: http://www.usgs.gov

Telephone: 1-888-ASK-USGS

Suggested citation:

Bushon, R.N., Stelzer, E.A., and Stoeckel, D.M., 2009, Results from a microbial source-tracking study at Villa Angela Beach, Cleveland, Ohio, 2007: U.S. Geological Survey Open-File Report 2009-1160, 9 p.

Any use of trade, product, or firm names is for descriptive purposes only and does not imply endorsement by the U.S. Government.

Although this report is in the public domain, permission must be secured from the individual copyright owners to reproduce any copyrighted material contained within this report. 


\section{Contents}

Abstract

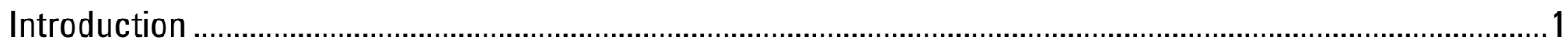

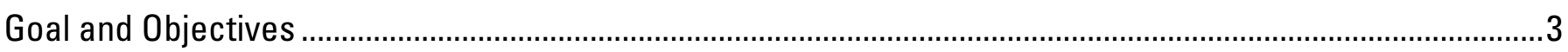

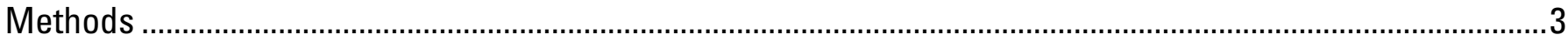

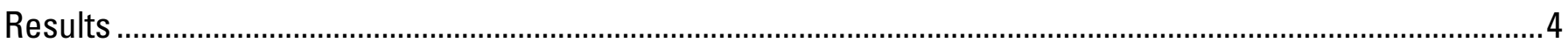

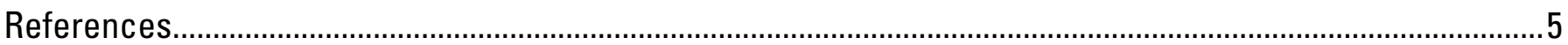

\section{Figure}

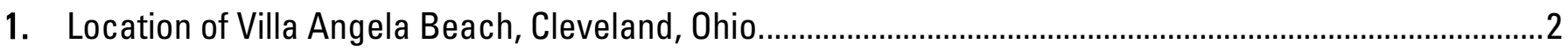

\section{Tables}

1. Standard curve characteristics for AllBac, Btheta, HF183, and dsRed2 microbial-source tracking (MST) markers. .

2. Environmental conditions at Villa Angela Beach at time of sampling. .7

3. DNA marker results for source samples collected at or near Villa Angela beach. 7

4. DNA marker results for environmental samples collected at or near Villa Angela beach (VA). 8 
[This page intentionally left blank for two-sided printing.] 


\title{
Results From a Microbial Source-Tracking Study at Villa Angela Beach, Cleveland, Ohio, 2007
}

\author{
By Rebecca N. Bushon, Erin A. Stelzer, and Donald M. Stoeckel
}

\begin{abstract}
During the 2007 recreational season at Villa Angela Beach in Cleveland, Ohio, scientists with the U.S. Geological Survey (USGS) and the Northeast Ohio Regional Sewer District (NEORSD) found high Escherichia coli (E. coli) concentrations that were not easily explained by results obtained to date in ongoing investigations of recreational water quality at the beach. To help understand the sources behind these elevated $E$. coli concentrations, the USGS and NEORSD sampled beach-area water for Bacteroides DNA markers. Bacteroides are a group of enteric bacteria that are being used in microbial source tracking, in hope that host-associated DNA markers could be used to indicate potential sources of $E$. coli in the Villa Angela environment. The USGS Ohio Water Microbiology Laboratory analyzed a total of 13 source samples (sewage and waterfowl feces) and 33 beach-area water and sand samples for three Bacteroides DNA markers. This report lists the results of those analyses, along with environmental conditions at Villa Angela on the dates that samples were collected.
\end{abstract}

\section{Introduction}

The U.S. Geological Survey (USGS), in cooperation with the Northeast Ohio Regional Sewer District (NEORSD), have been involved in a series of studies to help assess and predict recreational-water quality at several Cleveland-area beaches and to try to identify sources of contamination using multiple lines of evidence. During the 2007 recreational season at Villa Angela Beach in Cleveland, Ohio, scientists found high Escherichia coli (E. coli) concentrations that were not associated with the usual predictors or triggers for that particular shoreline area of Lake Erie. For example, during 2006, the data indicated that $E$. coli concentrations generally increased with rainfall, increased inputs from nearby Euclid Creek, and overflow events from the sewer system. In contrast, conditions at Villa Angela during the 2007 recreational season consisted of a prolonged dry weather period, fewer overflow events, and lower concentrations of bacteria in Euclid Creek than seen in previous years. Compared to the 2006 recreational season, 2007 had an increased number of exceedances of recreational water-quality standards, with a greater average concentration of E. coli (Lester Stumpe, Northeast Ohio Regional Sewer District, written commun., 2007). 


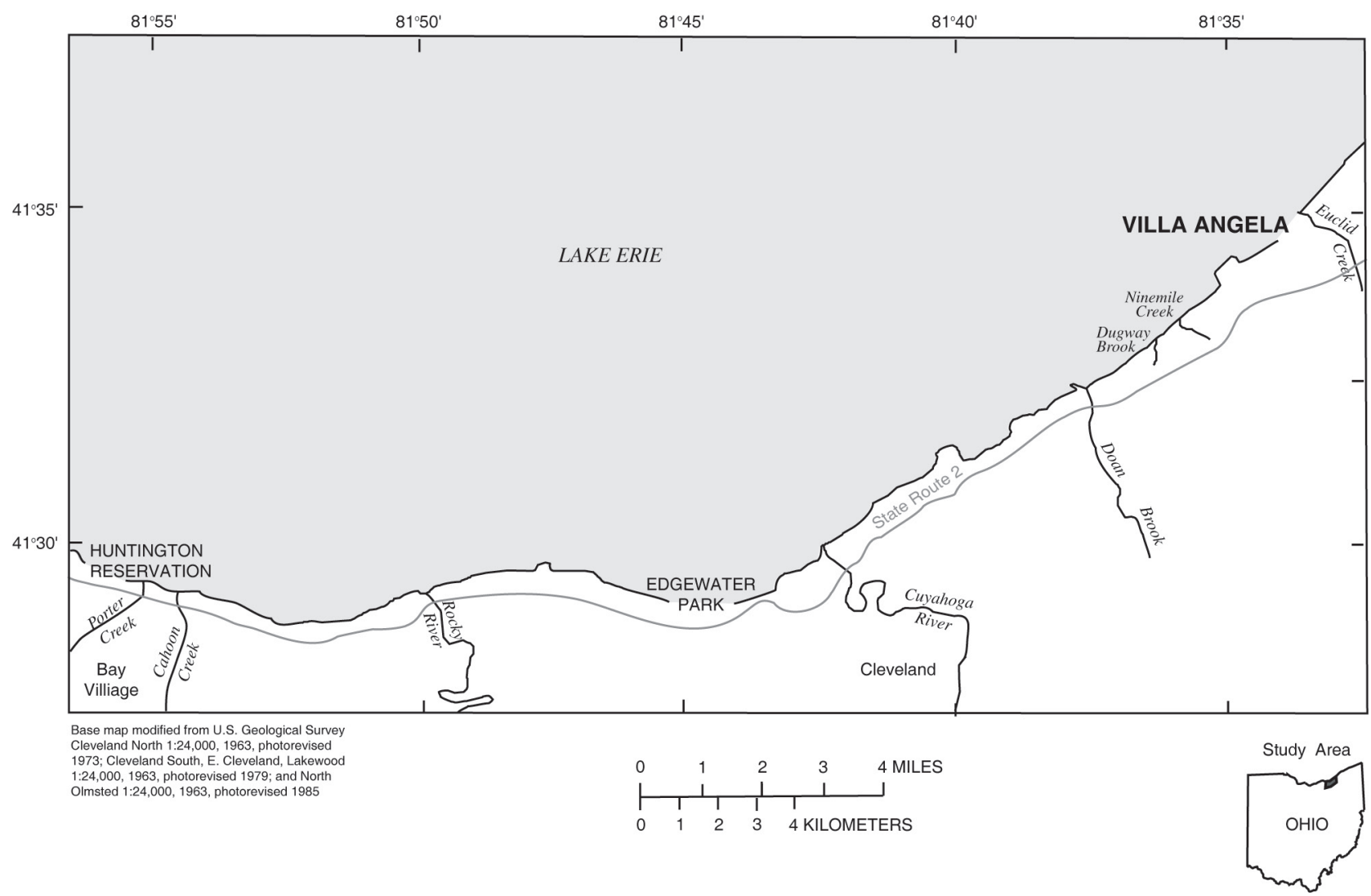

Figure 1. Location of Villa Angela Beach, Cleveland, Ohio.

In an attempt to understand the sources behind the elevated E. coli concentrations at Villa Angela in 2007, NEORSD began a series of investigations, including boat sampling of open water and spatial sampling in the beach area for concentrations of $E$. coli. The NEORSD approached the USGS for ideas regarding source-tracking possibilities in the study area. Recently, host-specific DNA markers have been used to track potential sources in the environment (Bernhard and Field, 2000; Layton and others, 2006; Santo Domingo and others, 2007).

The USGS has the capability to analyze water samples for Bacteroides DNA markers of general fecal contamination, as well as markers that are associated with human feces. The Bacteroidales are a dominant group of enteric bacteria that may have co-evolved with their hosts. For this reason, their host specificity has been investigated for use in microbial source tracking (Bernhard and Field, 2000). Researchers have done analyses on water samples by means of quantitative polymerase chain reaction (qPCR), which results in a relative quantity of each DNA marker. Human sources are not the only potential contaminants on the beach. In particular, waterfowl are also present in the area. At this time, few waterfowl DNA markers are available in the literature (Lu and others, 2007; Lu and others, 2008). 


\section{Goal and Objectives}

The overall goal of the study was to provide NEORSD with source-tracking information to aid in their understanding of elevated bacterial concentrations at Villa Angela Beach. Specific objectives were to determine the presence and relative quantity of MST markers in potential sources (waterfowl feces and sewage) and analyze source and beach samples by qPCR to determine relative quantities of Bacteroides DNA markers.

\section{Methods}

Collection of environmental data. Rainfall amounts were obtained from a National Weather Service (NWS) station at Burke Lakefront Airport (http://www.erh.noaa.gov/cle/). Turbidity was measured in nephelometric turbidity ratio units (NTRUs) by use of a Hach Model 2100P turbidimeter (Hach Company, Loveland, Colo.). Wave heights were measured by placing a survey rod in the water at the sampling location for 1 minute, and the minimum and maximum heights were recorded. The number of birds was counted at the time of sampling, which occurred between 8 and 10 a.m.

Source sampling. Sample collection of potential sources was done in August 2007 to ensure that the selected DNA markers were found in potential sources. Samples were collected from each of the following sources: influent and effluent from the Easterly Wastewater Treatment Plant $(\mathrm{n}=$ $4)$ and waterfowl feces from the beach area $(n=6)$. Additional samples collected for reference or for comparison to the beach samples were as follows: one control sample (offshore lake water with no fecal contamination as measured by $E$. coli), one combined-sewer-overflow (CSO) sample, and one stormwater outfall sample.

Beach sampling. Spatial sampling of the study area was done in July and August 2007 by NEORSD. Samples were collected over a range of weather conditions and E. coli concentrations. Samples were analyzed immediately for $E$. coli by membrane filtration and were filtered and stored in the freezer for subsequent DNA marker analysis. Each sampling effort involved the collection of five to six samples: one composite sample from the east and west locations, two additional beach water samples (special), two sand samples (one swash zone and one lake bottom), and one Euclid Creek sample.

All samples were analyzed for $E$. coli by the standard membrane-filtration technique (U.S. Environmental Protection Agency, 2006) and for three Bacteroides DNA markers:

- AllBac, a general fecal marker that is expected to be present in all sources (Layton and others, 2006)

- $\quad$ Two human fecal markers, qHF183 (Bernhard and Field, 2000) and Bacteroides thetaiotaomicron (Btheta) (Carson and others, 2005)

Additionally, Dr. Jorge Santo Domingo (U.S. Environmental Protection Agency, Cincinnati, Ohio) analyzed source and beach samples for a gull-specific DNA marker (Lu and others, 2008). Subsamples of the same DNA extracts were sent to USEPA for analysis. 
Quantitative PCR. Quantification was done by use of standard curves calculated from threshold cycles observed for decimal dilutions of plasmid-borne DNA target. Standard concentrations were calculated based on the total concentration of DNA in the plasmid solution and the known size of the target-containing plasmid. Characteristics of the standard curves are presented in Table 1.

Each qPCR run included a standard curve and a no-template control. The upper and lower limits of quantification (ULQ and LLQ, represented as the dynamic range in Table 1) were based on the range of standards that contributed to the linear portion of the standard curve. In all cases, the standard curve remained linear at both the highest standard and the lowest standard.

No-template control data were used to measure a limit of detection (LOD). The notemplate controls sometimes showed non-specific fluorescent signal during late cycles. In these cases, the mean and 99-percent confidence interval among cycle thresholds in no-template controls were calculated. To guard against false-positive results, the target concentration that corresponded with detection at the lower 99-percent confidence interval of multiple detections was used as the LOD. A cycle threshold higher than the LOD was not considered credible evidence that the sample contained detectable quantities of the marker.

The LLQ and the LOD were used to qualify low-concentration data. In cases where the LLQ was greater than the LOD, results higher than the LLQ were not qualified. Results between the LLQ and the LOD were qualified detectable, not quantified (DNQ). Results below the LOD were purged and considered nondetects. Conversely, when the LOD was greater than the LLQ, results higher than the LOD were not qualified. Results below the LOD were purged and considered nondetects.

Exogenous internal standard. DNA encoding red-fluorescent protein dsRed2 (Matz and others, 1999) was used as an internal standard that is not expected to be detected naturally in the fresh water environment. Approximately $2.5 \times 10^{6}$ cells of E. coli containing a dsRed 2 plasmid were added to each filtered sample immediately before extraction. Recovery of dsRed 2 marker was measured by qPCR and used as a qualitative measure of matrix inhibition. When dsRed2 recovery was lower than expected, the extract was diluted to overcome matrix inhibition.

\section{Results}

A total of 13 source samples and 33 beach samples were analyzed for DNA markers. Table 2 lists the environmental conditions at Villa Angela on the dates that samples were collected. Tables 3 and 4 list the results for the source samples and beach samples, respectively. These tables show the quantity of the AllBac and qHF183 markers the OWML analyzed for and the presence or absence of the gull marker the USEPA analyzed for. Calculated quantities were based on multiple runs of composite standard curves of known concentrations of each marker.

Results from the Btheta human-specific marker are not presented in tables 3 and 4. Of the four sewage samples analyzed, Btheta was detected in only one sample. Additionally, the marker 
was detected in four of the six bird source samples at low levels. Of the 33 beach samples, the marker was detected in 1 sample at a very low level. Therefore, Btheta does not appear to be a useful human-associated marker for this area.

Five lake water samples, collected in July 2007, were characterized as having no recent rainfall but high $E$. coli concentrations, ranging from 2,400 to 12,000 colony-forming units per 100 milliliters (cfu/100 mL) with a mean value of 5,000 cfu/100 mL. In these samples, the qHF183 human marker was found at quantifiable levels in 1 sample at a low concentration. The gull marker was present in 4 of the 5 samples.

In August 2007, nine lake water samples with no recent rainfall were collected. E. coli concentrations ranged from 20 to $580 \mathrm{cfu} / 100 \mathrm{~mL}$ with a mean value of $190 \mathrm{cfu} / 100 \mathrm{~mL}$. The qHF183 marker was found at quantifiable levels in 3 samples and the gull marker was present in 4 samples. Six lake water samples, also collected in August, were characterized as having recent rainfall. The $E$. coli concentrations ranged from 210 to $1,400 \mathrm{cfu} / 100 \mathrm{~mL}$ with a mean value of 630 $\mathrm{cfu} / 100 \mathrm{~mL}$. The qHF183 human marker was detected at quantifiable levels in all 6 samples. The gull marker was present in 4 samples.

Two samples were collected from Euclid Creek following recent rainfall. E. coli concentrations were 5,100 and 17,000 cfu/100 mL. The qHF183 human marker was present in both samples at the two highest concentrations found during this study. The gull marker was not present in either sample.

A total of ten sand samples were collected from Villa Angela Beach. E. coli concentrations ranged from 890 to 23,000 colony-forming units per gram of dry weight (cfu/g $\mathrm{g}_{\mathrm{dw}}$ ) with a mean value of 5,800 cfu $/ \mathrm{g}_{\mathrm{dw}}$. The $\mathrm{qHF} 183$ human marker was not found at quantifiable levels, while the gull marker had a weak presence in 3 samples. The AllBac general marker was either not detected or present at low concentrations.

\section{References}

Bernhard, A.E., and Field, K.G., 2000, A PCR assay to discriminate human and ruminant feces on the basis of host differences in Bacteroides-Prevotella genes encoding 16S rRNA: Applied and Environmental Microbiology, v. 66, no. 10, p. 4571-4574.

Carson, C.A.; Christiansen, J.M.; Yampara-Iquise, Helen; Benson, V.W.; Baffaut, Claire; Davis, J.V.; Broz, R.R.; Kurtz, W.B.; Rogers, W.M.; and Fales, W.H., 2005, Specificity of a Bacteroides thetaiotaomicron marker for human feces: Applied and Environmental Microbiology, v. 71, no. 8 , p. 4945-4949.

Layton, Alice; McKay, Larry; Williams, Dan; Garrett, Victoria; Gentry, Randall; and Sayler, Gary, 2006, Development of Bacteroides 16S rRNA gene TaqMan-based real-time PCR assays for estimation of total, human, and bovine fecal pollution in water: Applied and Environmental Microbiology, v. 72, no. 6, p. 4214-4224. 
Lu, J., Santo Domingo, J., and Shanks, O.C., 2007, Identification of chicken-specific fecal microbial sequences using a metagenomic approach: Water Research, v. 41, p. 3561-3574.

Lu, J., Santo Domingo, J.W., Lamendella, R., Edge, T., and Hill, S., 2008, Phylogenetic diversity and molecular detection of bacteria in gull feces: Applied and Environmental Microbiology, v. 74, no. 13, p. 3969-3976.

Matz, M.V., Fradkov, A.F., Labas, Y.A., Savitsky, A.P., Zaraisky, A.G., Markelov, M.L., and Lukyanov, S.A., 1999, Fluorescent proteins from nonbioluminescent Anthozoa species: Nature Biotechnology, v. 17, p. 969-973.

Santo Domingo, J.W., Bambic, D.G., Edge, T.A., and Wuertz, Stefan, 2007, Quo vadis source tracking? Towards a strategic framework for environmental monitoring of fecal pollution: Water Research, v. 41, no. 16, p. 3539-3552.

U.S. Environmental Protection Agency, 2006, Method 1603-Escherichia coli (E. coli) in water by membrane filtration using modified membrane-thermotolerant Escherichia coli agar (modified mTEC): Washington, D.C., Office of Water, EPA-821-R-06-011 [variously paginated]. 
Table 1. Standard curve characteristics for AllBac, Btheta, HF183, and dsRed2 microbialsource tracking (MST) markers.

\begin{tabular}{cccccc}
\hline MST marker & $\begin{array}{c}\text { Number of } \\
\text { compiled curves }\end{array}$ & Dynamic range & $\begin{array}{c}\text { Range of } \\
\text { amplification } \\
\text { efficiency (percent) }\end{array}$ & $\begin{array}{c}\text { Range of } \mathbf{R}^{2} \\
\text { values }\end{array}$ & $\begin{array}{c}\text { Limit of } \\
\text { detection }\end{array}$ \\
\hline AllBac & 9 & $1.2 \times 10^{1}-1.2 \times 10^{7}$ & $92-109$ & $0.985-0.999$ & 22 \\
Btheta & 4 & $5.7 \times 10^{1}-5.7 \times 10^{7}$ & $92-95$ & $0.992-0.995$ & $\mathrm{ND}^{*}$ \\
HF183 & 8 & $2.3 \times 10^{1}-2.3 \times 10^{7}$ & $93-102$ & $0.972-0.999$ & $\mathrm{ND}^{* *}$ \\
dsRed2 & 10 & $6.1 \times 10^{1}-6.33 \times 10^{8}$ & $90-104$ & $0.971-0.998$ & 1,000 \\
\hline
\end{tabular}

*The marker was never detected in a blank

**The marker was detected in one of 10 blanks; however, it was considered an outlier and was removed from the dataset because it was atypical and the replicate result was not detected.

Table 2. Environmental conditions at Villa Angela Beach at time of sampling.

\begin{tabular}{lccccrr}
\hline Date & $\begin{array}{c}\text { Rainfall (inches } \\
\text { in previous 24 } \\
\text { hours) }\end{array}$ & $\begin{array}{c}\text { Turbidity } \\
\text { (Nephelometric } \\
\text { Turbidity Ratio Units) }\end{array}$ & $\begin{array}{c}\text { Wave Height } \\
\text { (feet) }\end{array}$ & $\begin{array}{c}\text { Number of } \\
\text { geese }\end{array}$ & $\begin{array}{c}\text { Number of } \\
\text { gulls }\end{array}$ & Total birds \\
\hline $7 / 11 / 2007$ & 0 & 10.6 & 0.79 & 8 & 60 & 68 \\
$7 / 12 / 2007$ & 0 & 15.8 & 1.38 & 24 & 78 & 102 \\
$7 / 16 / 2007$ & 0 & 3.3 & 0.50 & 70 & 30 & 100 \\
$8 / 8 / 2007$ & 2.39 & 5.5 & 1.00 & -- & -- & 85 \\
$8 / 9 / 2007$ & 0.14 & 0.9 & 0.08 & -- & -- & 110 \\
$8 / 16 / 2007$ & 0 & 1.1 & 0.33 & -- & -- & 300 \\
$8 / 29 / 2007$ & 0 & 1.9 & 0.25 & 7 & 25 & 32 \\
$8 / 30 / 2007$ & 0 & 8.2 & 2.08 & 0 & 5 & 5 \\
\hline
\end{tabular}

-- Data not available. 
Table 3. DNA marker results for source samples collected at or near Villa Angela beach.

\begin{tabular}{|c|c|c|c|c|c|}
\hline \multirow{2}{*}{ Date } & \multirow{2}{*}{ Sample name } & \multirow{2}{*}{$\begin{array}{c}\text { E. coli } \\
\text { (colony-forming } \\
\text { units per } \\
100 \text { milliliters) }\end{array}$} & \multirow{2}{*}{$\begin{array}{c}\text { AllBac } \\
\text { general marker } \\
\text { Quantity } \\
\text { (per 100 milliliters) }\end{array}$} & \multirow{2}{*}{$\begin{array}{c}\text { qHF183 } \\
\text { human marker } \\
\begin{array}{c}\text { Quantity } \\
\text { (per } 100 \text { milliliters) }\end{array}\end{array}$} & \multirow{2}{*}{$\begin{array}{c}\text { USEPA } \\
\text { gull marker } \\
\text { Presence/absence }\end{array}$} \\
\hline & & & & & \\
\hline $8 / 7 / 2007$ & CSO & 260,000 & $17,000,000$ & $1,900,000$ & Absent \\
\hline $8 / 7 / 2007$ & Stormwater outfall & 7,000 & 100,000 & 1,500 & Absent \\
\hline $8 / 9 / 2007$ & Control site & -- & 300 & ND & Absent \\
\hline $8 / 9 / 2007$ & Easterly influent & 870,000 & 790,000 & 240,000 & Weak presence \\
\hline $8 / 9 / 2007$ & Easterly effluent & -- & 240,000 & 88,000 & Absent \\
\hline $8 / 29 / 2007$ & Easterly influent & $1,400,000$ & $1,300,000$ & 190,000 & Absent \\
\hline $8 / 29 / 2007$ & Easterly effluent & 36,000 & 44,000 & 14,000 & Absent \\
\hline $8 / 9 / 2007$ & Gull 1 & $57,000,000^{\mathrm{a}}$ & 5,600 & 6,500 & Absent \\
\hline $8 / 29 / 2007$ & Gull 2 Villa & $130,000,000^{\mathrm{a}}$ & ND & ND & Absent \\
\hline $8 / 29 / 2007$ & Goose 1 Villa & $49,000^{\mathrm{a}}$ & ND & ND & Absent \\
\hline $8 / 29 / 2007$ & Goose 2 Easterly & $4,600,000^{\mathrm{a}}$ & 14,000 & ND & Absent \\
\hline $8 / 29 / 2007$ & Goose 3 Villa & $<170^{\mathrm{a}}$ & 4,400 & ND & Absent \\
\hline $8 / 29 / 2007$ & Gull 3 Villa & $3,700^{\mathrm{a}}$ & 560 & 360 & Present \\
\hline
\end{tabular}

${ }^{a}$ Colony-forming units per gram of feces.

-- Not analyzed for.

ND, not detected. 
Table 4. DNA marker results for environmental samples collected at or near Villa Angela beach (VA).

\begin{tabular}{|c|c|c|c|c|c|}
\hline \multirow{2}{*}{ Date } & \multirow{2}{*}{ Sample name ${ }^{a}$} & \multirow{2}{*}{$\begin{array}{c}\text { E. coli } \\
\text { (colony-forming } \\
\text { units per } \\
100 \text { milliliters) }\end{array}$} & \multirow{2}{*}{$\begin{array}{c}\text { AllBac } \\
\text { general marker } \\
\text { Quantity } \\
\text { (per } \mathbf{1 0 0} \text { milliliters) }\end{array}$} & \multirow{2}{*}{$\begin{array}{c}\begin{array}{c}\text { qHF183 } \\
\text { human marker }\end{array} \\
\begin{array}{c}\text { Quantity } \\
\text { (per } 100 \text { milliliters) }\end{array}\end{array}$} & \multirow{2}{*}{$\begin{array}{c}\begin{array}{c}\text { USEPA } \\
\text { gull marker }\end{array} \\
\text { Presence/absence }\end{array}$} \\
\hline & & & & & \\
\hline $7 / 11 / 2007$ & VA Composite & 4,500 & 14,000 & 400 & Present \\
\hline $7 / 12 / 2007$ & VA Composite & 3,400 & 12,000 & ND & Present \\
\hline $7 / 12 / 2007$ & Euclid Beach & 12,000 & 43,000 & ND & Present \\
\hline $7 / 16 / 2007$ & VA Composite & 2,400 & 32,000 & DNQ & Present \\
\hline $7 / 16 / 2007$ & Euclid Beach & 2,700 & 21,000 & DNQ & Absent \\
\hline $8 / 8 / 2007$ & VA Sand & $23,000^{\mathrm{b}}$ & ND & ND & Weak presence \\
\hline $8 / 8 / 2007$ & VA Sand & $9,000^{\mathrm{b}}$ & ND & ND & Absent \\
\hline $8 / 8 / 2007$ & Euclid Creek & 5,100 & 56,000 & 8,400 & Absent \\
\hline $8 / 8 / 2007$ & VA Special & 750 & 22,000 & 2,300 & Absent \\
\hline $8 / 8 / 2007$ & VA Special & 780 & 6,000 & 280 & Present \\
\hline $8 / 8 / 2007$ & VA Composite & 1,400 & 31,000 & 2,000 & Weak presence \\
\hline $8 / 9 / 2007$ & VA Sand & $7,200^{b}$ & 1,300 & DNQ & Absent \\
\hline $8 / 9 / 2007$ & VA Sand & $3,700^{\mathrm{b}}$ & 4,800 & ND & Absent \\
\hline $8 / 9 / 2007$ & Euclid Creek & 17,000 & 40,000 & 2,400 & Absent \\
\hline $8 / 9 / 2007$ & VA Special & 210 & 7,600 & 1,200 & Absent \\
\hline $8 / 9 / 2007$ & VA Special & 250 & 6,500 & 1,200 & Present \\
\hline $8 / 9 / 2007$ & VA Composite & 400 & 14,000 & 490 & Present \\
\hline $8 / 16 / 2007$ & VA Sand & $2,000^{\mathrm{b}}$ & 1,400 & ND & Weak presence \\
\hline $8 / 16 / 2007$ & VA Sand & $890^{\mathrm{b}}$ & 780 & ND & Absent \\
\hline $8 / 16 / 2007$ & Euclid Creek & 550 & 13,000 & 1,400 & Absent \\
\hline $8 / 16 / 2007$ & VA Special & 54 & 4,800 & 220 & Absent \\
\hline $8 / 16 / 2007$ & VA Special & 24 & 6,300 & ND & Present \\
\hline $8 / 16 / 2007$ & VA Composite & 150 & 12,000 & ND & Present \\
\hline $8 / 29 / 2007$ & VA Sand & $3,000^{\mathrm{b}}$ & 1,600 & ND & Absent \\
\hline $8 / 29 / 2007$ & VA Sand & $1,700^{\mathrm{b}}$ & ND & DNQ & Weak presence \\
\hline $8 / 29 / 2007$ & VA Special & 20 & 1,100 & DNQ & Weak presence \\
\hline $8 / 29 / 2007$ & VA Special & 38 & 5,500 & ND & Absent \\
\hline $8 / 29 / 2007$ & VA Composite & 310 & 2,800 & 330 & Absent \\
\hline $8 / 30 / 2007$ & VA Sand & $2,000^{b}$ & 840 & ND & Absent \\
\hline $8 / 30 / 2007$ & VA Sand & $6,000^{\mathrm{b}}$ & ND & ND & Absent \\
\hline $8 / 30 / 2007$ & VA Special & 300 & 6,800 & 480 & Absent \\
\hline $8 / 30 / 2007$ & VA Special & 580 & 4,000 & ND & Weak presence \\
\hline $8 / 30 / 2007$ & VA Composite & 200 & 6,200 & DNQ & Absent \\
\hline
\end{tabular}

${ }^{\mathrm{a}}$ Sample names defined in methods section.

${ }^{\mathrm{b}}$ Colony-forming units per gram of dry weight.

ND, Not detected.

DNQ, Detected not quantified. 
